\title{
Implementasi Peraturan Pemerintah Nomor 46 Tahun 2011 Tentang Penilaian Prestasi Kerja Pegawai Negeri Sipil
}

\section{Implementation of Government Regulation Number 46 of 2011 concerning Assessment of Civil Servants Work Performance}

\author{
Sarjani Pasaribu'), R. Hamdani Harahap ${ }^{2)}$ \& Siti Mardiana ${ }^{3)}$
}

1) Magister Program Studi Administrasi Publik, Universitas Medan Area, Indonesia

2) Departemen Antropologi Sosial, Fakultas Ilmu Sosial dan Ilmu Politik,

Universitas Sumatera Utara, Indonesia

3) Fakultas Pertanian Universitas Medan Area, Indonesia

\section{Abstrak}

Permasalahan dalam penelitian ini adalah bagaimana mengimplementasikan Peraturan Pemerintah Nomor 46 Tahun 2011 tentang penilaian kinerja pegawai negeri terutama di Kantor Wilayah Kementerian Hukum dan Hak Asasi Manusia Sumatera Utara. Penelitian ini telah dilakukan sejak Desember 2018 hingga Januari 2019 dan telah berlangsung di Kantor Wilayah Kementerian Hukum dan Hak Asasi Manusia Sumatera Utara. Metode deskriptif kualitatif digunakan dalam penelitian ini. Observasi, wawancara dan dokumentasi adalah sebagai pengumpulan data penelitian ini. Orang yang diwawancarai adalah kepala divisi administrasi, kepala departemen umum, kepala departemen kepegawaian dan sepuluh (10) karyawan dari masing-masing divisi untuk memperoleh rincian sesuai dengan kebutuhan penulis. Hasil penelitian ini menggambarkan implementasi penilaian kinerja pegawai negeri, berdasarkan peraturan pemerintah Nomor 46 Tahun 2011 di Kantor Wilayah Kementerian Hukum dan Hak Asasi Manusia Sumut telah dilaksanakan dengan baik. Peran empat (4) faktor untuk keberhasilan implementasi kebijakan seperti: 1. Komunikasi, 2. Sumber Daya, 3. Posisi, 4. Struktur birokrasi dapat dipenuhi meskipun belum sempurna. Pegawai negeri sipil yang menjadi sasaran kebijakan penilaian kinerja pegawai negeri sipil tidak mengalami kesulitan untuk mendapatkan informasi penilaian kinerja pegawai negeri sipil. Informasi yang ada telah memberikan kepastian kepada para pegawai negeri tentang menggambarkan target kinerja sipil.

Kata Kunci: Implementasi, Peraturan Pemerintah, Penilaian Kinerja, Pegawai Negeri

\section{Abstract}

The problem of this research is how to implement Government Regulation Number 46 Year 2011 on the appraisal of civil service performance especially at the Regional Office of Ministry of Law and Human Rights of North Sumatera. This research has been conducted since December 2018 until January 2019and has taken place at the Regional Office of Ministry of Law and Human Rights of North Sumatera. The Qualitative descriptive method is used in this research. Observation, interviewing and documentation are as data collection of this research. The main interviewees are the head of division of administration, the head of general department, the head of sub staffing department and ten (10) employees from each division to obtain detailed according to the need of the writer. The result of this research describes the implementation of the appraisal of civil service performance, based on government regulation Number 46 Year 2011at the Regional Office of Ministry of Law and Human Rights of North Sumatera has been implemented well. The role of four (4) factors to successful policy implementation such as: 1. Communication, 2. Resources, 3. Disposition, 4. Structure of the bureaucracy can be fulfilled although it has not been perfect. The civil servants that become the policy target of the appraisal of civil service performance do not have any difficulties to obtain the information of the appraisal of civil service performance. The existing information has given the certainty to the civil servants of the describing the performance target of civil.

Keywords: Implementation, Government Regulation, Appraisal Performance, Civil Service.

How to Cite: Sarjani Pasaribu, R. Hamdani Harahap \& Siti Mardiana (2020), Implementasi Peraturan Pemerintah Nomor 46 Tahun 2011 Tentang Penilaian Prestasi Kerja Pegawai Negeri Sipil. Strukturasi: Jurnal Ilmiah Magister Administrasi Publik, 2(1) 2020: 70-78

*E-mail: sarjanipasaribu@gmail.com

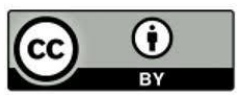




\section{PENDAHULUAN}

Sasaran kinerja pegawai merupakan kegiatan tugas jabatan dan target yang harus dicapai oleh seorang pegawai PNS dalam kurun waktu tertentu penilaian yang bersifat nyata dan dapat diukur, yang disusun dan disepakati bersama antara Pejabat Penilai dengan Pegawai Negeri Sipil yang dinilai. Nyata dan dapat diukurartinya kegiatan yang realistis dapat dilaksanakan dan hasilnya dapat dihitung dalam satuan angka, seperti jumlah, persentase dan lamanya waktu. Dalam menetapkan SKP, pejabat penilai harus mempertimbangkan usul bawahan dan waktu penyelesaian beban kerja unit organisasi.

Penilaian kinerja PNS dengan pendekatan SKP membawa harapan baru dalam pengembangan karir PNS. Asumsinya jika diterapkan berdasarkan prinsip telah dikemukakan (objektif; terukur; akuntabel; partisipatif; dan transparan) tentu diharapkan membawa dampak positif bagi kemajuan organisasi. Para pegawai akan termotivasi bekerja dengan sebaik-baiknya, karena diberi penghargaan berupa paket remunerasi (tambahan penghasilan). Bagi organisasi juga bermanfaat dalam rangka pengembangan program human resources development (pengembangan SDM), diantaranya dapat menempatkan orang pada posisi yang tepat.

Kehadiran PP No 46 tahun 2011 tentang Penilaian Pestasi Kerja PNS dengan kewajiban penyusunan SKP bagi setiap individu PNS mengundang sikap optimistis dan pesimistis di kalangan pegawai. Pegawai yang memiliki pemikiran moderat cenderung optimistis menyikapi kehadiran sistem baru penilaian PNS tersebut, apalagi jika penilaian kinerja dengan SKP ini digunakan sebagai acuan dalam pemberian tunjangan kinerja, sangat manusiawi. Sebaliknya pegawai yang konservatif cenderung bersikap pesimistis, menurut mereka, pada akhirnya SKP juga terjebak ke dalam seremoni yang hanya formalitas saja seperti halnya DP3.

Apapun alasannya, mau tidak mau, setiap PNS harus siap menghadapi perubahan paradigma baru sistem penilaian kinerja sebagaimana diuraikan di atas. Ada beberapa langkah yang fundamental yang harus disiapkan oleh pimpinan lembaga/instansi pemerintah dalam menyongsong sistem penilaian kinerja PNS dengan SKP. Kesiapan PNS dalam menyambut sistem baru penilaian prestasi kerja sangat tergantung dengan beberapa hal antara lain: a) Penataan kelembagaan, b) Prinsip-prinsip Pengembangan Kapasitas (Capacity Building), dan c) Sarana Kerja Utama (Siregar, Kadir, \& Muda, 2019; Munthe, Warjio \& Kariono, 2018; Marpaung, 2011)

Penyelesaian SKP 2018 dapat dikatakan sudah baik di lingkungan kantor wilayah Kementerian Hukum dan HAM Sumatera Utara. Beberapa orang pegawai menunjukkan hasil penilaian dengan kategori sangat baik yang bersumber dari hasil penilaian pencapaian SKP dan aspek perilaku yang harus sangat baik pula. Namun hal ini tidak serta menunjukkan bahwa penilaian kinerja pegawai telah dilakukan sebagaimanadiharapkan karena seperti kehadiran pegawai yang dikontrol dengan mesin absen otomatis (finger print) hanya bisa mendeteksi saat waktu masuk kerja dan jam pulang kerja, sementara kenyataannya dijumpai juga pegawai yang sering keluar saat jam kerja. Artinya kemampuan perangkat keras sebagai alat kontrol terbatas untuk membantu mengevaluasi aspek perilaku. Kenyataan menunjukan bahwa proses 
penilaian pelaksanaan pekerjaan PNS cenderung terperangkap ke dalam proses formalitas saja.

Penilaian SKP Tahun 2018 dan penyusunan SKP Tahun 2019 di kantor wilayah Kementerian Hukum dan HAM Sumatera Utara sudah dilaksanakan tetapi tidak sesuai dengan tujuan PP No 46 tahun 2011 tentang Penilaian Pestasi Kerja PNS. Hal ini disebabkan kurangnya sosialisasi penyusunan sasaran kerja pegawai (SKP) sehingga PNS mengalami kesulitan dalam menyusunnya. Keadaan ini ditambah dengan suatu keadaan yang diperintahkan oleh PP No 46 tahun 2011 tentang Penilaian Pestasi Kerja PNS bahwa penilaian prestasi kerja diberikan oleh atasan (pejabat Penilai). Kenyataan yang ditemukan bahwa penilaian tersebut masih diserahkan kepada PNS yang bersangkutan. Artinya masih terdapat penyimpangan peraturan yang seharusnya memberikan penilaian secara mutlak adalah atasan langsung sebagai pejabat penilai bukan individu yang dinilai yang menetapkan nilai terhadap dirinya sendiri. Pegawai (PNS) menilai dirinya masing-masing baru kemudian diajukan kepada atasannya untuk ditandatangani. Hal ini tidak sejalan dengan maksud dan tujuan daripada Peraturan Pemerintah Nomor 46 tahun 2011 yang menitikberatkan penilaian prestasi kerja PNS pada sistem penilaian prestasi kerja berdasarkan dan menjamin objektifitas penilaian terhadap prestasi kerja PNS.

\section{METODE PENELITIAN}

Berdasarkan tujuan penelitian, penelitian ini dikategorikan ke dalam penelitian deskriptif, karena penelitian ini berusaha untuk menggambarkan fenomena atau gejala yang dalam hal ini fenomena mengenai faktor-faktor penghambat kenaikan pangkat jabatan fungsional analis kepegawaian. Selain itu, penelitian ini dilakukan tanpa adanya campur tangan peneliti terhadap objek penelitian. Hal ini sesuai dengan pendapat Kountur (2004:105) bahwa penelitian deskriptif memberikan gambaran lebih detail mengenai suatu gejala atau fenomena yang diteliti tanpa ada perlakuan terhadap objek yang diteliti.

Berdasarkan teknik pengumpulan data, penelitian ini termasuk penelitian kualitatif. Didalam penelitian ini peneliti akan menggunakan wawancara mendalam, observasi dan studi dokumen sebagai instrument pengumpulan data. Pedoman wawancara ini dapat berkembang sesuai dengan kondisi yang ada di lapangan (Prasetyo dan Jannah,2005:4950). Dalam penelitian ini, peneliti ingin mengetahui apa saja faktor-faktor penghambat kenaikan pangkat pilihan para analis kepegawaian yang berada pada Kantor Wilayah Kementerian Hukum dan HAM Sumatera Utara. Untuk itu, peneliti menggunakan wawancara mendalam agar data yang diperoleh lebih detail dan mampu menjelaskan permasalahan yang diangkat peneliti. Metode pengumpulan data dilakukan untuk menentukan relevan tidaknya penelitian dengan permasalahan yang ditetapkan. Dalam penelitian ini peneliti menggunakan metode pengumpulan data kualitatif, yang terdiri atas studi kepustakaan dan wawancara mendalam.

\section{HASIL DAN PEMBAHASAN}


Berdasarkan analisis keberperanan empat unsur penting implementasi kebijakan (komunikasi, Sumber Daya, disposisi dan struktur Birokrasi), empat unsur tadi memiliki daya dukung yang berbeda-beda. Ada unsur yang dipenuhi dalam implementasi kebijakan dan ada unsur yang tidak memenuhi persyaratan seperti yang disyaratkan oleh Edward III sehingga kurang mendukung proses implementasi kebijakan.

Dari keempat unsur yang dinyatakan oleh Edward III, yang paling mendukung terhadap implementasi kebijakan Penilaian prestasi kerja adalah Sumber Daya, Disposisi dan Struktur Birokrasi. Staf yang mencukupi dan sikap positif yang ditunjukkan oleh para pelaksana kebijakan, terutama dalam hal komitmen, adalah bukti adanya keseriusan para pelaksana kebijakan penilaian prestasi kerja (Handoko, 2016; Dongoran, Harahap, \& Tarigan, 2018; Pinayungan, Kusmanto, \& Isnaini, 2018; Ismail, Harahap, \& Kariono, 2018).

Dalam hal Sumber Daya, adanya staf yang mencukupi dan memiliki kompetensi untuk melaksanakan kebijakan, adanya pemberian wewenang dan tanggungjawab serta tersedianya fasilitasuntuk melancarkan implementasi kebijakan penilaian prestasi kerja. Adapun Disposisi, sikap positif dan komitmen yang kuat dari para pelaksana kebijakan serta adanya penempatan staf berdasarkan tugas dan keahliannya, benar-benar mendukung pelaksanaan kebijakan penilaian prestasi kerja. Struktur Birokrasi juga mendukung implementasi kebijakan. dalam hal Struktur Birokrasi, unsur SOP sudah jelas karena sudah ada panduan yang jelas dari Pemerintah pusat yaitu peraturan kepala BKN nomor 1 tahun 2013 yang sudah mengatur tentang pelaksanaan PP nomor 46 tahun 2011. Dan dalam unsur pembagian tanggungjawab juga sudah berjalan dengan baik.

\section{Penyusunan Sasaran Kinerja Pegawai}

Kantor Wilayah Kementerian Hukum dan HAM Sumatera Utara merupakan suatu organisasi lembaga resmi Pemerintah yang dapat melaksanakan kegiatan penetapan kebijakan operasional pembinaan, pengawasan dan pengendalian peningkatan kapasitas bina ideologi dan wawasan kebangsaan, kewaspadaan nasional ketahanan seni, budaya, agama, kemasyarakatan dan ekonomi serta politik dalam negeri yang searah dengan kebijakan umum Pemerintah pusat yang berpedoman pada peraturan Pemerintah nomor 46 tahun 2011 tentang penilaian prestasi kerja PNS maka dari itu uraian berikut akan diawali dengan penjelasan penyusunan sasaran kinerja pegawai.

Sasaran kerja pegawai yang sering disebut dengan SKP adalah rencana kerja dan target yang akan dicapai oleh seorang PNS. Setiap PNS wajib menyusun SKP, karena pada dasarnya SKP akan memuat tugas jabatan dan target yang harus dicapai dalam kurun waktu penilaian yang bersifat nyata dan dapat diukur. SKP yang telah disusun harus disetujui dan ditetapkan oleh pejabat penilai, SKP yang disusun oleh PNS yang tidak disetujui oleh pejabat penilai maka keputusannya diserahkan kepada atasan pejabat penilai dan bersifatfinal.

Adapun penyusunan SKP dilakukan dan ditetapkan setiap tahunnya pada awal bulan Januari. Dalam hal terjadinya perpindahan pegawai setelah bulan Januari maka yang bersangkutan tetap menyusun SKP pada awal bulan sesuai dengan surat perintah melaksanakan tugas atau surat perintah menduduki jabatan. PNS yang tidak menyusun 
SKP akan dikenakan sanksi atau akan dijatuhi hukuman disiplin sesuai dengan ketentuan peraturan perundang-undangan yang mengatur mengenai disiplin PNS, adapun sanksi atau hukuman yang akan diberikan kepada pegawai yang tidak menyusun atau membuat SKP yaitu berupa, teguran lisan, teguran tertulis, pernyataan tidak puas secara tertulis, penundaan kenaikan gaji berkala selama satu tahun, penundaan kenaikan pangkat selama satu tahun, dan penurunan pangkat setingkat lebih rendah selama satu tahun.

Penyusunan sasaran kinerja pegawai itu bersifat wajib dilakukan oleh setiap PNS guna untuk mengetahui rencana kerja pegawai dan target yang ingin dicapai oleh setiap PNS terkhususnya PNS yang terdapat di Kantor Wilayah Kementerian Hukum dan HAM Sumatera Utara. Pada dasarnya dilihat dari hasil wawancara diatas bahwasannya penyusunan SKP oleh setiap PNS yang ada di Kantor Wilayah Kementerian Hukum dan HAM Sumatera Utara sudah baik dan berjalan lancar, hal ini dapat dilihat dari setiap tahunnya para pegawai tidak pernah terlambat dalam melakukan penyusunan sasaran kinerja pegawai.

Dalam penyusunan SKP tentunya terdapat aspek-aspek yang menjadi bahan penilaian SKP, maka dari itu instansi atau pegawai menyusun dan menetapkan standar teknis kegiatan sesuai dengan karakteristik, sifat, jenis kegiatan, dan kebutuhan tugas masing-masing jabatan.

\section{Pelaksanaan Sasaran Kinerja Pegawai}

Dalam setiap lembaga negara atau lembaga Pemerintah selalu terdapat yang namanya penilaian prestasi kerja untuk setiap pegawai dari setiap instansi yang ada. Terkait dengan penilaian kinerja pegawai maka terdapat pelaksanaan sasaran kinerja pegawai yang dimana pelaksanaan SKP harus lah sesuai dengan Peraturan Pemerintah Nomor 46 tahun 2011.

Prestasi kerja pegawai haruslah sesuai dengan pelaksanaan sasaran kinerja pegawai yang mana hasil kerja yang ingin dicapai oleh setiap PNS pada satuan organisasi haruslah sesuai dengan sasaran kerja pegawai dan perilaku kerja pegawai. Pelaksanaan sasaran kinerja pegawai atau SKP yang tidak tercapai dikarenakan oleh faktor diluar kemampuan individu PNS maka pelaksanaan penilaian SKP didasarkan pada pertimbangan kondisi penyebabnya. Dalam menjalankan tugas tambahan yang diberikan oleh pimpinan atau pejabat penilai yang berkaitan dengan tugas jabatan dan atau menunjukkan kreativitas yang bermanfaat bagi organisasi dalam melaksanakan tugas jabatan, maka hasil penilaian dari pelaksanaan SKP menjadi bagian dari penilaian capaian SKP.

Dari hasil wawancara diatas dapat disimpulkan bahwasannya pelaksanaan SKP di Kantor Wilayah Kementerian Hukum dan HAM Sumatera Utara pelaksanaannya maksimal dan semua pegawai menjalankan dan menyusun SKP mereka dan melaksanakannya dengan baik dan sesuai dengan ketentuan yang terdapat di peraturan Pemerintah yang ada dan telah ditentukan.

Dari hasil wawancara diatas dapat disimpulkan bahwasannya pelaksanaan sasaran kinerja pegawai di Kantor Wilayah Kementerian Hukum dan HAM Sumatera Utara sudah baik dan sesuai dengan Peraturan Pemerintah Nomor 46 Tahun 2011 tentang penilaian 
prestasi kerja PNS. Realisasi capaian sasaran kinerja pegawai negeri sipil setiap tahunnya sesuai dengan target, dimana ditargertkan 12 bulan dan dapat terealisasikan 12 bulan. Dalam hal ini penulis mengamati penilaian capaian sasaran kinerja pegawai negeri sipil dalam melaksanakan kegiatan tugas jabatan dapat terealisasi sesuai dengan target.

Berdasarkan penelitian terdahulu yang diteliti oleh Nurroniah (2017), bahwa Implementasi Peraturan Pemerintah No.46 Tahun 2011 tentang Penilaian Prestasi Kerja Pegawai Negeri Sipil di Kantor Badan Kesatuan Bangsa dan Politik Kota Samarinda sudah terlaksana dengan baik dan maksimal, semua pegawai telah menjalankan dan menyusun SKP dengan tepat waktu, capaian dan realisasi sesuai dengan target serta pelaksanakannya sesuai dengan peraturan pemerintah yang berlaku.

Fokus dari penelitian ini adalah bagaimana penilaian prestasi kerja PNS di Kantor Badan Kesatuan Bangsa dan Politik Kota Samarinda dan bagaimana cara penyusunan serta pelaksanaan SKP nya bila dilihat dari sisi PP Nomor 46 Tahun 2011 tentang penilaian prestasi kerja PNS.

Berbeda dengan penelitian yang dilakukan oleh Subhan Fajri (2015) di kantor camat Medan Sunggal, bahwa implementasi Peraturan Pemerintah Nomor 46 Tahun 2011 tidak terlaksana secara efektif, pegawai hampir semua belum menyusun SKP tepat waktu. Hal ini terjadi karena pegawai tidak memahami cara menyusun SKP dan penilaian SKP yang seyogiyanya dilakukan oleh atasan langsung, kenyataannya masih dilakukan oleh pegawai itu sendiri (menilai diri sendiri). Kurangnya sosialisasi dan komunikasi terhadap pegawai menjadi salah satu penyebab implementasi PP Nomor 46 Tahun 2011 tidak terlaksana secara efektif. Penelitian ini juga menggunakan metode deskriptif kualitatif.

Fokus dari penelitian ini menggunakan teori Edward III untuk mengetahui bagaimana implementasi PP No. 46 Tahun 2011 tentang Penilaian Prestasi Kerja PNS serta mengetahui faktor yang berperan dalam implementasi PP No. 46 Tahun 2011 tentang Penilaian Prestasi Kerja PNS. Unsur-unsur tersebut adalah communication, resources, dispositions dan bureuacratic structure. Hasil penelitian yang dianalisis dari keempat unsur diatas menunjukkan bahwa keempat unsur tersebut belum dilaksanakan dengan efektif di kantor camat Medan Sunggal

Penelitian terdahulu yang dilakukan oleh Mahfuddin (2016) dengan judul Implementasi Peraturan Pemerintah Nomor 53 Tahun 2010 Tentang Disiplin Pegawai Negeri Sipil (Studi Kasus Pada Sekretariat Daerah Kabupaten Pidie) adalah menggunakan metode deskriptif kualitatif. Penelitian tersebut menggunakan teori Edward III untuk mengetahui bagaimana implementasi PP No. 53 Tahun 2010 tentang Disiplin Pegawai Negeri Sipil di sekretariat daerah kabupaten Pidie. Hasil penelitiannya yaitu bahwa dalam pelaksanaan disiplin pegawai negeri sipil pada Kantor Sekretariat Daerah Kabupaten Pidie masih belum sempurna dikarenakan masih ada pegawai yang melanggar peraturan, hal itu disebabkan karena belum adanya sanksi yang tegas dalm penerapan disiplin kerja pegawai negeri di kantor tersebut.

Sebagian pegawai beranggapan pelanggaran tersebut tidak ada konsekuensi bagi para pegawai yang bersangkutan. Kemudian kurangnya pengawasan dari kepala 
pimpinan bagian-bagian tertentu yang memungkinkan para pegawai keluar masuk kantor pada jam-jam kerja atau setidak-tidaknya mengulur-ngulur waktu dalam menyelesaikan tugas.

Fokus penelitian ini sesuai teori Edward III adalah unsur struktur birokrasi dimana struktur birokrasi memiliki pengaruh yang signifikan terhadap implementasi kebijakan. Hasil penelitian menunjukkan bahwa sebagian besar PNS di Lingkungan Sekretariat Daerah Kabupaten Pidie menjadikan variabel disiplin sangat tergantung kepada seberapa disiplin atasan mereka bukan berdasarkan kepada kesadaran pribadi sebagai public servicer.

Hasil penelitian di Kantor Wilayah Kementerian Hukum dan HAM Sumatera Utara tentang implementasi Peraturan Pemerintah Nomor 46 Tahun 2011 ini hampir sama implementasinya dengan penelitian Nurroniah (2017) yaitu pelaksanaannya sudah maksimal sesuai dengan Peraturan Pemerintah, namun masih terdapat satu atau dua orang yang tidak membuat SKP tepat waktu dan juga tidak mengisi jurnal harian sehingga penilaian SKP nya pun terlambat. Hal ini terjadi karena faktor dari personal pegawai itu sendiri seperti malas dan apatis, meskipun sudah ditegur dan diberi sanksi oleh atasan langsungnya.

Fokus penelitian ini hampir sama dengan penelitian terdahulu Subhan Fajri (2015 dan Mahfuddin (2016) dimana penelitian sama-sama menggunakan teori Edward III untuk menganalisis Implementasi Peraturan Pemerintah Nomor 46 Tahun 2011 tentang penilaian prestasi kerja PNS. Hasil pengamatan penulis dilapangan bahwa terindikasi ketidaksesuaian antara beberapa hasil wawancara dengan realita pelaksanaan PP Nomor 46 Tahun 2011 di Kanwil Sumut.

\section{SIMPULAN}

Komunikasi; Proses Implementasi Peraturan Pemerintah Nomor 46 Tahun 2011 tentang Penilaian Prestasi Kerja Pegawai Negeri Sipil padaKantor Wilayah Kementerian Hukum dan HAM Sumatera Utaradari sisi penyampaian pesan, pelaksana kebijakan program penilaian prestasi kerja terhadap PNS di setiap Divisi sudah berjalan dengan lancar dan tepat sasaran.

Sumber Daya; Staf yang menangani program penilaian prestasi kerja telah dibekali dengan pengetahuan dengan seringnya mengikuti pelatihan tentang segala hal terkait program penilaian prestasi kerja.

Disposisi;Dalam kaitannya dengan sikap para pelaksana kebijakan terutama dalam hal komitmen, mulai dari pelaksana kebijakan di tingkat bawah sampai di level atas padaKantor Wilayah Kementerian Hukum dan HAM Sumatera Utara telah berjalan dengan baik dan memiliki komitmen yang kuat untuk melaksanakan kebijakan serta adanya penempatan staf berdasarkan tugas dan keahliannya.

Struktur Birokrasi; Kanwil Kemenkumham Sumut telah memiliki SOP yang jelas karena sudah ada panduan yang jelas dari pemerintah pusat yaitu peraturan kepala BKN nomor 1 tahun 2013 yang sudah mengatur tentang ketentuan pelaksanaan Peraturan Pemerintah nomor 46 tahun 2011, termasuk dalam unsur pembagian tanggungjawab juga sudah berjalan dengan baik. 


\section{DAFTAR PUSTAKA}

Arikunto, S, (2008), Prosedur Penelitian Ilmiah, Jakarta, PT. Rineka Cipta.

Barthos, B, (2005), Manajemen Sumber Daya Manusia Suatu PendekatanMakro, Jakarta, PT Bumi Aksara.

Bungin, B, (2010), Penelitian Kualitatif: Komunikasi, Ekonomi, Kebijakan Publik dan Ilmu Sosial Lainnya, Cetakan Keempat. Jakarta, Kencana Prenada Media Group,

Dessler, G. (2007). Manajemen Sumber Daya Manusia. Jakarta, Prenhallindo.

Dongoran, H.S. Harahap, R.H. \& Tarigan, U. (2018). Implementasi Peraturan Walikota Medan tentang Unit Pelaksanaan Teknis Pelayanan Kebersihan dan Bank Sampah. Jurnal Administrasi Publik (Public Admnistration Journal). 8 (1): 47-64.

Douglas, H.T. and Goodale, G.J, (2006), Human Resources Management, Strategy, Design and Impelementation, Scott Foresman and Company, Glenview.

Edwards III, and George C, (2002), Implementing Public Policy. Texas Congressional Quartely Press.

Faustino, and Cardoso Gomes, 2003, Manajemen Sumber Daya Manusia, Yogyakarta, Penerbit Andi.

Glueck, J, Lawrence, R, and William, F. (2007), Manajemen Strategi dan Kebijakan Perusahaan, Jakarta, PT. Erlangga.

Handoko, D., (2016), Implementasi Peraturan Menteri Pertanian Nomor 32 Tahun 2011 Tentang Pengelolaan Dan Pelayanan Informasi Publik, Jurnal Administrasi Publik (Public Admnistration Journal), 6 (2): 147-159.

Handoko, T.H, (2001), Manajemen Personalia Dan Sumber Daya Manusia, Yogyakarta, Penerbit BPFE.

Hariandja, M.T.E. (2002), Manajemen Sumber Daya Manusia: Pengadaan, Pengembangan, Pengkompensasian, dan Peningkatan Produktivitas Pegawai, Jakarta, Gramedia Widiasarana Indonesia

Hasibuan, M, (2016), Manajemen Sumber Daya Manusia, Edisi Revisi, Jakarta, PT. Bumi Aksara,

Ismail, W,H, Harahap, R.H. \& Kariono. (2018). Implementasi Peraturan Menteri Agama RI Nomor 45 Tahun 2015 Tentang Disiplin Kehadiran PNS Di Lingkungan Kementerian Agama. Jurnal Administrasi Publik (Public Admnistration Journal). 8 (1): 124-146.

Mangkunegara, A.A dan Prabu, A. (2001). Manajemen Sumber Daya Manusia Perusahaan, Bandung: PT Remaja Rosda Karya.

Manullang. M.M, (2001). Manajemen Personalia. Yogyakarta, Gajah Mada University Press.

Marpaung, H.W. (2011). Implementasi Peraturan Daerah Kabupaten Labuhanbatu Nomor 37 Tahun 2008 Tentang Pembentukan Organisasi Dan Tata Kerja Kecamatan, Jurnal Administrasi Publik (Public Admnistration Journal), 1 (1): 29-50

Moleong, L.J. (2006), Metodologi Penelitian Kualitatif, Bandung, Remaja Rosda Karya.

Munthe, S. Warjio \& Kariono. (2018). Implementasi Peraturan Pemerintah Nomor 18 Tahun 2016 tentang Perangkat Daerah pada Penataan Kelembagaan Sekretariat Daerah. JPPUMA: Jurnal Ilmu Pemerintahan dan Sosial Politik UMA (Journal of Governance and Political UMA), 6 (1): 38-52.

Nasucha, C, (2004), Reformasi Administrasi Publik: Teori dan Praktek, Jakarta: PT Gramedia Widiasarana.

Nawawi, H, (2008), Manajemen Sumber Daya Manusia Untuk Bisnis Yang Kompetitif, Yogyakarta, Gadjah Mada University Press.

Nazir Mohd, (2005), Metode Penelitian, Bogor, Penerbit Ghalia Indonesia

Nugroho, R, (2004), Kebijakan Publik Formulasi, Implementasi dan Evaluasi, Jakarta, PT Elex Media Komputindo Kelompok Gramedia.

Pinayungan, J. Kusmanto, H. \& Isnaini. (2018). Implementasi Peraturan Menteri Perhubungan Republik Indonesia Tentang Standar Keselamatan Lalu Lintas Dan Angkutan Jalan. Jurnal Administrasi Publik (Public Admnistration Journal). 8 (1): 108-123.

Rao, TV, (2006), Penilaian Prestasi Kerja, Jakarta, PT. Binaman Pressindo.

Rivai, V, (2005), Manajemen Sumber Daya Manusia Untuk Perusahaan dari Teori ke Praktik, Jakarta, PT Raja Grafindo Persada.

Salam, S.D, (2002), Manajemen Pemerintahan Indonesia, Jakarta, Penerbit Djambatan.

Siregar, I.H, Kadir, A. \& Muda, I. (2019). Implementasi Peraturan Daerah Kota Medan Nomor 10 Tahun 2012 Tentang Retribusi Pelayanan Kebersihan. PERSPEKTIF, 8 (1): 15-19.

Soeprihanto, J, (2001), Penilaian Kinerja dan Pengembangan Karyawan, Yogyakarta, Universitas Gadjah Mada.

Stoner, F, and Gilbert. (2006). Manajemen, Jilid II, Alih Bahasa Alexander Sindoro, Jakarta, Prenhallindo.

Sugiyono, (2005), Memahami Penelitian Kualitatif, Cetakan Kesatu, Bandung: CV. Alfabeta

Sugiyono, (2008), Metode Penelitian Kuantitatif Kualitatif dan R \& D, Bandung: CV. Alfabeta.

Tunggal, A.W, (2003), Manajemen Suatu Pengantar, Jakarta, Penerbit Rineka Cipta.

Widodo, J, (2011), Analisis Kebijakan Publik.Jawa Timur, Penerbit Banyumedia. 
Sarjani Pasaribu, R. Hamdani Harahap \& Siti Mardiana, Implementasi Peraturan Pemerintah Nomor

Winarno, B, (2005), Teori dan Proses Kebijakan Publik, Yogyakarta, Media Presindo.

\section{PERATURAN PEMERINTAH DAN UNDANG-UNDANG}

Peraturan Pemerintah Nomor 46 Tahun 2011 tentang Penilaian Prestasi Kerja Pegawai Negeri Sipil.

Peraturan Pemerintah Nomor 10 Tahun 1979 tentang Penilaian Pelaksanaan Pekerjaan Pegawai

Peraturan Pemerintah Nomor 96 Tahun 2000Tentang Wewenang Pengangkatan, Pemindahan, Dan Pemberhentian Pegawai Negeri Sipil

Peraturan Kepala Badan Kepegawaian Negara Nomor 1 Tahun 2013 tentang Ketentuan Pelaksanaan Peraturan Pemerintah Nomor 46 Tahun 2011 tentang Penilaian Prestasi Kerja Pegawai Negeri Sipil

Undang-undang Nomor 8 Tahun 1974 tentang Pokok-Pokok Kepegawaian.

Undang-undang No. 43 Tahun 1999 tentang Pokok-Pokok Kepegawaian

Undang Undang Nomor 18 Tahun 1961 Tentang Ketentuan Pokok-Pokok Kepegawaian

Undang Undang Nomor 8 Tahun 1974 Tentang Pokok-Pokok Kepegawaian.

Undang Undang No. 43 Tahun 1999 Tentang Perubahan Atas UU No. 8/1974

Peraturan Pemerintah Nomor 46 Tahun 2011 Tentang Penilaian Prestasi Kerja Pegawai Negeri Sipil.

\section{INTERNET}

http://www.kemenkumham.go.id

https://bkn.go.id 